\title{
EMANSIPASI PEREMPUAN DALAM RANAH DOMESTIK PADA NOVEL "LITTLE WOMAN" KARYA LOUISA MAY ALCOTT
}

\author{
Bella Saputri Indrapuri, Eggy Fajar Andalas \\ Pendidikan Bahasa dan Sastra Indonesia \\ Universitas Muhammadiyah Malang \\ bellaputriayuii@gmail.com \\ andalaseggy@gmail.com
}

\begin{abstract}
ABSTRAK: Penelitian ini dilatarbelakangi oleh peran ganda perempuan yang harus pintar membagi waktu antara keluarga dan pekerjaan. Penelitian ini menggunakan pendekatan kualitatif deskriptif. Temuan hasil penelitian terungkap bahwa : 1. Gambaran umum peran ganda pada perempuan yaitu peran sebagai ibu rumah tangga. 2. Kendala yang dirasakan perempuan dalam menjalankan semua perannya berasal dari internal dan eksternal. Kendala internal yaitu lelah fisik, lelah mental. dan kendala eksternal yaitu adanya keterbatasan waktu. 3. Dampak yang terjadi dalam menjalankan peran gandanya berdampak positif dan negatif. Dampak positif nya bisa membantu perekonimian keluarga adanya kerja sama antara ibu dan anak dalam menyelesaikan tugas rumah.
\end{abstract}

KATA KUNCI: kehidupan keluarga, peran ganda perempuan.

\begin{abstract}
ABSTRAC: This research is motivated by the dual role of women who must be smart in dividing the time between family and work. This study uses a descriptive qualitative approach. The findings of the research revealed that : 1) A general description of the dual role of women, namely the role of housewives. 2) The constrains felt by women in carrying out all their roles came from internal and external. Internal constraints namely pysical fatigue, mental fatigue. And external constraints, namely the limitation of time. 3) The impact that accurs in carrying out its dual role has a positive and negative impact the positive impact can help the family economy with cooperation between mother and child in completing homework.
\end{abstract}

KEYWORDS: family life, the dual role of women.

\section{PENDAHULUAN}

Bekerja merupakan hal yang paling utama dalam memenuhi kebutuhan keluarga, dalam suatu rumah tangga bekerja merupakan suatu kewajiban jika mereka tidak bekerja maka mereka tidak akan bisa memenuhi kebutuhannya. Dalam keluarga yang mencari nafkah atau bekerja merupakan kewajiban dari kepala keluarga. Tidak heran jika kepala rumah tangga banting tulang setiap hari. Seiring perkembangan zaman peranan laki-laki yang bekerja sekarang sudah beruba yaitu sang istri atau perempuan ikut dalam bekerja. Dalam kajian sastra melalui pendekatan feminisme terdapat keterkaitan yang bersinambungan antara faktor biologis, pengalaman, wacana,

\section{ketidaksadaran}

dan masalah sosialekonomi (Selden,1986, hlm. 132). Jadi hubungan keseimbangan antara faktor yang berhubungan dengan kajian feminisme. Pada kenyataannya sebagai male-female secara biologis dalam ilmu sosial lebih dikenal sebagai gerakan kesetaraan gender, sebaliknya, gender dan jenis kelamin yaitu masculine-feminisme (Ratna, 2004, hlm. 184-185). Dengan begitu terdapat hubungan terhadap emansipasi perempuan sebagai salah satu kaitannya dengan kesetaraan hak. Hal ini menyebabkan kaum feminisme meneliti berbagai permasalahan dengna menggunakan berbagai macam teori yang cocok untuk mengatasi permasalan feminisme. Dengan berbagai macam 
perjuangan yang dilakukan akhirnya menghasilkan gerakan feminisme yang lahir pada perempuan berkulit putih dieropa. Sejak saat itu feminismefeminisme mulai berkembang banyak yang bermunculan feminisme-feminisme baru seperti feminisme radikal, feminisme liberal, feminisme sosial, atau marxis.

Feminisme adalah sebuah paham yang menentang budaya maupun kebijakan politik yang tidak menguntungkan kaum perempuan. Kata feminisme bisa diartikan sebagai: $A$ recognition of an imbalance of power between the sexes, with woman in a subordinate role to men: Pengakuan tentang ketidakseimbangan kekuatan antara dua jenis kelamin, dengan peranan wanita berada dibawah pria (June Hannam, 2007, hlm. 22). Paham ini lantas berkembang menjadi sebuah gerakan di negara-negara barat pada sekitar tahun 1970-an. Feminisme sebagai sebuah pergerakan untuk mengakhiri sexism, eksploitasi berdasarkan seks dan operasi terhadapnya, (Bell Hooks, 2000). Pada abad ke XIX feminisme berkembang pesat, pada saat itu perempuan mulai mengalami eksploitasi yang cukup berat. Dengan berbagai macam perjuangan yang dilakukan akhirnya mengahasilkan feminism yang lahir pada perempuan bekulit putih di Eropa (Lubis, 2006, hlm. 74-75). Sejak saat itulah perkembangan feminism berkembang pesat (Pravita, 2009, hlm. 7-4). Salah satu hal yang ditekankan dari gerakan feminis ini adalah perempuan ingin mendapatkan akses untuk pekerjaan yang layak, perempuan ingin mendapatkan akses pendidikan, dan perempuan ingin mendapatkan hak-nya. Perjuangan inipun terus berjalan, seiring dengan berkembangnya gerakan perempuan di berbagai negara, termasuk di negara-negara Arab Saudi.

Tidak semua perempuan paham akan makna feminisme yang ISSN Elektronik : 2614-7718 ISSN Cetak : : 2086-0609 sesungguhnya. Pertama, karena perempuan masa kini tidak lahir di era perempuan-perempuan benar-benar dijadikan mahluk subordinat di dalam kehidupan masyarakat. Perempuan kini tidak perlu merasakan apa yang dirasakan Kartini seperti 'dipingit' dan dirampas hak pendidikannya, walaupun sebagian kecil masih ada masyarakat yang menerapkan budaya ini. Kedua, perempuan yang kini mengklaim dirinya sebagai feminis lahir melalui sebuah kontemplasi pikiran perempuan dengan pengalaman. Pemikiran ini sangat dipengaruhi oleh buku-buku studi literatur feminisme, dan juga buku-buku yang mengangkat pengalaman perempuan yang tertindas oleh budaya patriarki. Kate Millett mengistilahkan patriarki (pemerintahan ayah) untuk menguraikan sebab penindasan perempuan. Patriarki meletakkan perempuan di bawah laki-laki atau memperlakukan perempuan sebagai lelaki yang inferior (Raman Selden, 1996, hlm. 139).

Novel Little Woman merupakan salah satu novel yang menceritakan sebuah perjuangan seorang ibu. Salah satu tokoh utama Seorang ibu yang membesarkan ke 4 orang anak perempuan yang mempunyai karakter berbeda-beda yang bernama Meg, Jo, Beth, dan Amy. Amy yang memiliki karakter yang berbeda dari yang lain, dari yang keibuan dan pemalu sampai yang tomboy, untung mereka memiliki ibu yang bisa mengerti dengan perbedaan karakter masingmasing anaknya sementara bapaknya yang sedang berjuang di medan perang saudara. Perjuangan seorang ibu yang berperan sebagai ibu dan ayah untuk anak-anaknya selalu memiliki cara sendiri untuk mendidik keempat anaknya. Seorang ibu belajar memberikan rasa tanggung jawab kepada anaknya tanpa harus mengeluarkan kata-kata yang lantang dengan menunjukkan sebuah keadaan 
pada anak-anaknya maka hati mereka akan senantiasa bergerak untuk menegakkan tanggung jawabnya sebagai seorang anak. Tugas seorang ibu dengan mengurus keempat anak-anaknya sangat lah berat, yang biasa tugas tersebut dilakukan oleh seorang ayah tapi ini dilakukan oleh ibunya sendiri seperti mendidik, mencari nafkah hal ini tentu sangat tidak mudah untuk dilakukan oleh seorang ibu. Nilai feminisme yang dapat diunggah, ibu tersebut melakukan gerakan emansipasi dan tidak sepenuhnya untuk bergantung pada seorang pria karena kenyataannya banyak tugas seorang pria yang bisa dilakukan oleh seorang wanita.

Pada cerita yang terdapat pada novel Little Woman terdapat berbagai macam permasalahan yang dialami oleh perempuan itu. yang mereka alami pada berbagai aspek mulai dari masalah sosial ekonomi. Penelitian feminisme pernah dilakukan oleh Widyarini Susilo Putri Jurusan Pendidikan Bahasa dan Sastra Indonesia Universitas Merdeka Malang. Alasan menganalisis novel little woman adalah untuk sarana alternatif Pendidikan Karakter dikalangan Remaja Indonesia. Hasil penelitian tersebut adalah novel yang menceritakan kehidupan sehari-hari yang mempunyai beberapa karakter yang berbeda-beda, mereka mendapat banyak pelajaran hidup seperti taat beragama, maka akan baik pula pada 17 karakter yang lain seperti dialami oleh anak-anak keluarga March. Pendidikan karakter dapat dijalankan dengan metode yang menyenangkan dengan membaca kisah anak-anak yang beranjak dewasa, dengan membaca membuat "terdidik" namun tidak merasa "digurui". Penelitian ini membuktikan bahwa karya sastra asing juga bisa memberikan kontribusi positif, selama proses pembacaannya didasari dengan pegangan 5 nilai Pancasila yang sudah berakar kuat.

ISSN Elektronik : 2614-7718

ISSN Cetak : : 2086-0609
Tujuan penulis meneliti novel little woman karena tokoh tokoh yang terdapat pada novel ini, semua nya adalah perempuan yang memiliki tingkat kesabaran dalam mendidik dan menafkahi keempat anak-anaknya yang ayah nya sedang berjuang di medan perang saudara. Fokus penelitian feminisme dari novel little woman adalah meneliti perjuangan seorang perempuan yang mengasuh keempat anaknya. Mengungkapkan nilainilai penting individu perempuan beserta pengalaman-pengalaman yang dialami bersama dan perjuangan yang mereka lakukan. Gerakan feminisme merupakan gerakan perjuangan dalam rangka mentransformasikan sistem dan struktur sosial yang tidak adil menuju keadilan bagi kaum laki-laki dan perempuan (Fakih, 2007, hlm. 78-79). Oleh karena itu, femenisme menghendaki kemandirian perempuan, tidak hanya tergantung kepada kaum laki-laki.

Teori feminisme memfokuskan diri pada pentingnya kesadaran mengenai persamaan hak antara perempuan dan laki-laki dalam semua bidang. Teori ini berkembang sebagai reaksi dan fakta yang di masyarakat, yaitu adanya konflik kelas, ras, dan terutama adanya konflik gender. Feminisme mencoba untuk menghilangkan pertentangan antara kelompok yang lemah yang dianggap lebih kuat. Lebih jauh lagi, feminisme menolak ketidakadilan sebagai masyarakat partiarki, menolak sejarah dan filsafat sebagai disiplin yang berpusat pada laki-laki (Ratna, 2017, hlm. 186). Feminis khususnya masalah-masalah mengenai wanita pada umumnya dikaitan dengan emansipasi, gerakan kaum perempuan untuk menuntut persamaan hak dengan kaum laki-laki baik dalam politik dan ekonomi maupun gerekan sosial budaya pada umumnya.

Cerita yang terdapat pada novel little woman memiliki permasalahan yang 
diambil dari pengalaman nyata dari pengarang yaitu Louisa May Alcott. Dengan pengarang yang berjenis kelamin perempuan, hubungan antara pengarang dengan tokoh memiliki perasaan seolaholah pengarang ikut hadir dan merasakan permasalahan yang ia buat.

\section{METODE}

Dalam mengkaji novel "Little Women" karya Loisa May Alcott, penelitian menggunakan jenis penelitian kualitatif. Penelitian kualitatif merupakan jenis penelitian yang mempunyai karakeristik dengan menyatakan keadaan yang sewajarnya tanpa adanya perubahan pada data. Data yang digunakan bukanlah data tentang angka-angka melainkan katakata atau gambaran. Penelitian ini menggunakan penelitian kualitatif karena bertujuan untuk memahami dan meneliti bentuk-bentuk permasalahan mengenai eksploitasi serta konservatif para perempuan amerika menggunakan cara deskripsi dalam bentuk analisis atau katakata (Maulana, 2013:273). Pemahaman terhadap penelitian ini dimaksudkan untuk memanifestasikan pada kesetaraan hak seta menuntut keadilan antara laki-laki dengan perempuan yang terdapat pada obyek material yang dikaji.

Untuk melakukan hal tersebut digunakan pendekatan feminisme. Pendekatan ini memandang dari kehidupan perempuan yang diambil dari segi permasalahan yang sudah dialami pada perempuan yang memiliki variasi wujud dari berbagai permasalahan tersebut pada novel little women mempertimbangkan permasalahan yang terjadi pada para tokoh perempuan yang ada di dalamnya. Mulai dari keluarga, tradisi dan ekonomi.

Penellitian ini menggunakan sumber data berupa novel "little women" karya Louisa May Alcott tahun 1868 dan terdiri dari 489 halaman. Data yang ISSN Elektronik : 2614-7718 ISSN Cetak : : 2086-0609 digunakan berupa dialog antar tokoh dan narasi. Sumber data penelitian ini adalah novel berjudul Little Women Karya Louisa May Alcott. Novel dengan tebal halaman 499 mengankat cerita tentang amak-anak keluarga March dalam masa pertumbuhan, bersosialisasi, serta menjalani rintangan kehidupan. Alcott menciptakan 4 sosok anak perempuan yang paling populer dalam sastra Amerika. Buku ini diterbitkan di Amerika tepatnya di Boston, Massachusetts oleh Robert Brothers. Data yang digunakan dalam penelitian ini menggunakan data bentuk kata-kata, frasa, dan kalimat dalam novel Little Women kartya Louisa May Alcott.

Penelitian ini menggunakan instrumen berupa peneliti dan panduan analisis data. Peneliti bertindak sebagai instrumen karena peneliti bertindak sebagai perencana, pelaksana, pengumpul data, analisis, mengamati data, analisis, mengamati data, dan penyimpul hasil penelitian (Andalas, 2017, hlm. 187). Maksudnya peneliti menjadi alat keseluruhan disaat proses melakukan penelitian instrumen panduan analasis data berupa kolom untuk mengelompokkan data sesuai dengan rumusan masalah. Hal ini mempermudah peneliti dalam menganalisis data penelitian.

\section{HASIL DAN PEMBAHASAN}

Berbicara mengenai peran ganda, perempuan yang mempunyai empat orang anak ini merupakan perempuan yang mempunyai peran ganda. Mereka tinggal di sebuah rumah/kerajaan, menafkahi anak-anaknya, membesarkan anakanaknya, mendidik anak-anaknya, semua pekerjaan tersebut dilakukan dalam satu waktu dan perempuan yang mempunyai peran ganda harus bisa membagi waktunya antara pekerjaan diluar rumah atau didalam rumah. Dalam novel Little Women yang dibuat oleh Loisa May 
Alcott, terdapat banyak pesan moral tentunya dalam hal feminisme. March membesarkan empat orang anak perempuan yang bernama Meg, Jo, Beth, dan Amy. Mereka memiliki karakter yang berbeda-beda mulai dari keibuan, pemalu, dan sampai yang tomboy. Untunglah mereka mempunyai seorang ibu yang bisa mengerti perbedaan karakter itu, sementara bapak mereka bertugas di medan perang saudara. dalam hal ini tampak jelas perjuangan seorang ibu yang berperan sebagai ibu dan ayah. hal ini dia lakukan dengan penuh semangat. March selalu mempunyai cara dalam mendidik keempat anaknya tanpa harus menggurui apalagi mengancam.

\section{Perjuangan Seorang Ibu dalam Menghidupi Keluarga}

Ibu adalah wanita yang telah melahirkan kita. Sebutan ibu mungkin terdengar biasa ditelinga, sebutan yang sepintas telah biasa didengar diberbagai tempat dan waktu tanpa sebuah makna. Apa makna dibalik sebutan ibu? bukan hanya sebuah sebutan saja. Ibu adalah seorang wanita yang telah malahirkan anaknya ke dunia dengan susah payah, rasa sakit yang luar biasa, sampai mempertaruhkan nyawa. Betapa banyak perjuangan dan pengorbanan yang beliau lakukan sampai saat ini. Sungguh besar jasa perjuangan seorang ibu, sehingga tidak akan pernah sanggup dibayar dengan apapun. Seperti perjuangan seorang ibu yang diceritakan dalam novel Little Women karya Louisa May Alcott. Bentukbetuk emansipasi pada novel Little Women karya Louisa May Alcott, dalam novel ini banyak ditemukan bentukbentuk emansipasi perempuan. Bentukbentuk dapat terlihat aspek 1) Pendidikan 2) Pekerjaan 3) sosial.

ISSN Elektronik : 2614-7718 ISSN Cetak : 2086-0609

\section{A. Bentuk-bentuk emansipasi wanita dalam novel Little Women pada aspek Pendidikan}

Pendidikan adalah usaha sadar dan terencana untuk memberikan bimbingan atau pertolongan dalam mengembangkan potensi jasmani dan rohani yang diberikan oleh orang dewasa kepada anak untuk mencapai kedewasaanya serta mencapai tujuan agar anak mampu melaksanakan tugas hidupnya secara mandiri. Suatu kematangan yang bertitik akhir pada optimalisasi perkembangan/pertumbuhan, baru dapat tercapai bilamana berlangsung melalui proses demi proses kearah tujuan perkembangan atau pertumbuhan. Usaha kependididkan adalah proses yang terarah dan bertujuan, yaitu mengarahkan anak didik (manusia) kepada titik optimal kemampuannya. Sedangkan tujuan yang hendak di capai adalah terbentuknya kepribadian yang bulat dan utuh sebagai manusia individual dan sosial. Pendidikan adalah usaha sadar dan terencana untuk mewujudkan suasana belajar dan proses pembelajaran agar peserta didik aktif mengembangkan potensi dirinya untuk memiliki kekuatan spiritual, keagaaman, pengendalian diri, kepribadian, kecerdasan serta keterampilan yang diperlukan dirinya, masyarakat, bangsa dan negara. Menurut (H. Fuad Ihsan, 2005, hlm. 1) menjelaskan bahwa dalam pengertian yang sederhana dan umum maka pendidikan sebagai usaha manusia untuk menumbuhkan dan mengembangkan potensi-potensi pembawaan baik jasmani maupun rohani sesuai dengan nilai-nilai yang ada di dalam masyarakat dan kebudayaan. Usaha-usaha yang dilakukan untuk menanamkan nilai-nilai dan norma-norma tersebut serta mewariskan kepada generasi berikutnya untuk dikembangkan dalam hidup dan kehidupan yang terjadi dalam suatu proses pendidikan sebagai usaha manusia melestarikan hidupnya. 
"Sesekali tidak mengerjalakan tugas, pasti tidak masalah, pikiran mereka. Namun, ketika petang menjelang dan makan malam belum terhidang, mereka sadar telah melakukan kesalahan , membersihkan seisi rumah serta menyiapkan makanan. March membiarkan anak-anaknya melakukan percobaan sehingga mereka dapat mengerti dan sendirinya akhibat dari pilihan yang mereka ambil" (hal. 16 bab 1)

Dalam kutipan yang ada dalam novel tersebut, ada bentuk pengasuhan yang sangat mulia, yaitu seorang ibu yang belajar memberikan rasa tanggungjawab yang tinggi terhadap anak-anaknya. Walaupun tanpa harus menggurui dan mengeluarkan kata-kata yang lantang, dengan menunjukkan sebuah keadaan pada anak-anaknya, maka hati mereka akan senantiasa tergerak untuk menegakkan tanggungjawabnya sebagai seorang anak. Hakikatnya untuk pembentukan mental dan karakter seorang anak biasanya dilakukan oleh seorang laki-laki yang terutama adalah ayahnya sendiri. March sebagian seorang ibu dengan lugas bisa melakukan kewajiban yang seharusnya dilakukan oleh seorang ayah. mulai dari mendidik, menafkahi sampai membesarkan.

Hasil analisis data diatas, dapat disimpulkan bahwa dalam mendidik anakanaknya Ibu March tidak pernah mengeluarkan kata-kata kasar atau lantang kepada anak-anaknya. dan ibu March selalu memberi tanggungjawab kepada anaknya agar hati anak-anaknya senantiasa tergerak sebagai tanggungjawab seorang anak.

"Selamat Natal putri-putri kecilku! Aku senang kalian langsung membacanya, dan mudah-mudahan akan begitu terus." (hal. 37 Bab 2 paragraf 3)

ISSN Elektronik : 2614-7718 ISSN Cetak : 2086-0609
Dari data tersebut tokoh Ibu March mengajarkan anak-anaknya sifat taat dalam beragama dengan cara menyenangkan seperti membuat anakanaknya tertarik untuk membaca bukubuku mempunyai hubungan dengan ajaran agama yang diyakini oleh mereka.

Hasil analisis, dapat disimpulkan bahawa Ibu March untuk membiasakan anak-anaknya membaca buku yang mempunyai hubungan dengan ajaran agama, karena dengan dibiasakan seperti itu anak-anak March akan senang sekali membaca buku, disamping itu juga belajar tentang keagamaan.

\section{B. Bentuk-bentuk emansipasi wanita dalam novel Little Women pada Aspek Pekerjaan}

Dalam kehidupan manusia selalu mengadakan bermacam-macam aktivitas. Salah satu aktivitas itu diwujudkan dalam gerakan-gerakan yang dinamakan kerja. Bekerja mengandung arti melaksanakan suatu tugas yang diakhiri dengan buah karya yang dapat dinikmati oleh manusia yang bersangkutan. Faktor pendorong penting yang menyebabkan manusia bekerja adalah adanya kebutuhan yang harus dipenuhi. Aktivitas dalam kerja mengandung unsur suatu kegiatan sosial, menghasilkan sesuatu, dan pada akhirnya bertujuan untuk memenuhi kebutuhannya. Namun demikian dibalik tujuan yang tidak langsung tersebut orang bekerja untuk mendapatkan imbalan yang berupa upah atau gaji dari hasil kerjanya itu. Jadi pada hakikatnya orang bekerja, tidak saja untuk mempertahankan kelangsungan hidupnya, tetapi juga bertujuan untuk mencapai taraf hidup yang lebih baik (As'ad, 2002, hal. 46). Pekerjaan adalah sesuatu yang dikerjakan untuk mendapatkan nafkah atau pencarian masyarakat yang sivbuk dengan kegiatan atau pekerjaan sehari-hari akan memiliki waktu yang lebih untuk memperoleh 
informasi. Pekerjaan adalah sesuatu yang dilakukan untuk mencari nafkah. Berbicara mengenai bekerja dan pekerjaan, seorang karyawan memiliki tugas atau pekerjaan yang menjadi tanggungjawab. Hal ini berarti karyawan harus dapat menyelesaikan pekerjaannya sesuai dengan rencana yang telah ditetapkan perusahaan. Secara kualitas, hasil kerja karyawan dari waktu ke waktu harus lebih baik, semakin variatif dam dapat diselesaikan dalam jangka waktu yang lebih singkat. Sedangkan secara kuantitas, hasil kerja karyawan harus dapat meningkat dalam hal jumlah (Hasibuan, 2003, hal. 35).

\section{"Anak-anak, bagaimana kabar kalian hari ini? Ada begitu banyak pekerjaan, menyiapkan kotak-kotak itu untuk besok, sampai-sampai ibu tidak bisa pulang untuk makan siang. Apa ada orang datang, Beth? Bagaimana denganmu Meg, masih masuk angin? Jo, kamu kelihatan kelelahan setengah mati. Kesinilah dan cium ibu sayang." (hal 23 bab 1)}

Pada kutipan data terserbut Keempat bersaudara March sangat menghargai bekerja keras dan melaksanakan tugas-tugas selalu tepat waktu dalam penuh tanggungjawab. Mereka bekerja dan belajar dengan tekun untuk kehidupan mereka dikala kehidupan mereka terpuruk dan jatuh dalam keadaan yang tidak menguntungkan. Namun, mereka tak pernah putus asa, mereka masih bisa tersenyum dan terus melanjutkan hidup, berjuang bersama untuk seluruh anggota keluarga untuk penghidupan dan dengan berjalannya waktu serta oleh kedisiplinan bersikap mereka bisa melalui permasalahan hidup

Hasil analisis tersebut, kondisi ibu March sangat kelelahan karena ia seharian sudah bekerja keras sampai-sampai lupa untuk pulang menemani anak-anaknya makan siang, lalu ibu March menanyakan kabar anak-anaknya setelah pulang bekerja.

\section{Bentuk-bentuk emansipasi wanita dalam novel Little Women pada Aspek Sosial}

Kehidupan sosial merupakan cerminan nyata situasi yang terjadi didalam masyarakat. Berbicara tentang masyarakat maka kita akan menemukan sebuah dinamika tanpa batas yang terjadi. Kemajuan pergerakan suatu masyarakat tidak lepas dari pengaruh internal dan eksternal yang terjadi. Didalam lingkungan masyarakat terdiri dari komunitas penduduk yang secara sadar berkelompok dan bekerja sama. Secara umum Mulyadi S. (2003, 23) mengelompokkan penduduk berdasarkan ciri-ciri tertentu, yaitu : 1) biologis, meliputiumur dan jenis kelamin. 2) sosial, antara lain meliputi tingkat pendidikan, status perkawinan. 3) ekonomi, meliputi penduduk yang aktif secara ekonomi, lapangan pekerjaan, jenis pekerjaan, tingkat pendapatan dan sebagainya. Dalam perjalanan kehidupan sosial kemasyarakatan saat ini ternyata terdapat ancaman-ancaman yang berpotensi merusak tatanan nilai-nilai dalam masyarakat (Buchori, 2001, hal. 79-80). Setiap masyarakat merupakan suatu kebulatan dimana masing-masing unsur saling mempengaruhi. Dasar semua unsur sosial adalah ikatan emosional, tak ada konflik antara individual dengan kelompok, oleh karena itu tunduk kepada tujuan kelompoknya. Peleburan dari kelompok-kelompok sosial, kebinaan dan taat merupakan petunjuk petunjuk bagaimana memperlakukan warga-warga kelompok maupun warga dari kelompok lainnya. 
"apa aku boleh pergi dan membantu membawakan makanan ini untuk anakanak malang itu?"

"kalian akan ikut pergi dan membantuku, setelah pulang nanti kita akan makan roti dan susu untuk sarapan dan mencukupcukupkan untuk makan siang" (hal 38 bab 2)

Pada kutipan data tersebut Ibu March selalu mengunjungi orang-orang yang membutuhkan, mereka membutuhkan makanan dan selimut. Membuat anak-anaknya meniru apa yang dilakukan ibunya. Anak-anak March pada akhirnya terkenal akan kebaikannya, ramah terhadap semua orang. Bertanggungjawab tidak terhadap dirinya sendiri, tapi terhadap Tuhan yang dibuktikan dengan peduli terhadap orang lain

Hasil analisis diatas, ibu March sangat peduli dengan orang-orang yang kekurangan, meskipun kebutuhan ibu March berkecukupan untuk mengasuh anak-anaknya, tetapi ibu March masih bisa untuk berbagi dengan sesama, dan anak-anaknya pun akan meniru kebiasaan ibunya, jadi ibu March memberikan tanggungjawab bukan untuk dirinya sendiri tapi juga untuk orang lain.

\footnotetext{
"Ibu tidak akan mengatakan apa-apa tentang uang kita, dan dia tida inginkita mengorbankan semuanya. Aku yakin kita sudah bekerja cukup keras, jadi kita pantas menikmati hasil hasilnya" (hal 11 bab 1)
}

Pada kutipan data tersebut saat keluarga March mengalami masalah perekonomian, anak-anak March berusaha tidak membebankan orang tuanya dengan mandiri dan tidak meminta hal yang anehaneh yang tidak bisa diberikan oleh orang tuanya. Bahkan tokoh yang bernama Jo seorang kakak, diberusaha membantu dengan menulis dan menjualnya lagi hal yang mempunyai nilai tinggi bagi wanita pada zaman itu. dan dia menjual rambutnya.

Hasil analisis data tersebut, bahwasannya ada banyak jalan untuk penghidupan, dari hal bagi banyak orang misal, Jo dapat menemukan cara mempublikasikan tulisannya, mengembangkan kemampuan untuk berpikir kritisnya agar menghasilkan, dan itu berhasil. Hal-hal kecil yang dapat memotifasi adik-adiknya, awalnya sering gagal dan bahkan penolakan, namum penolakan tersebut bukan menjadi akhir.

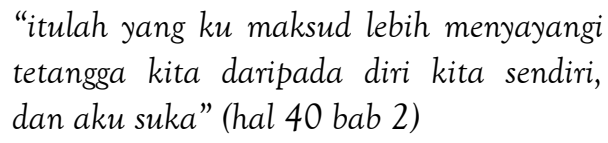

Pada kutipan data tersebut anakanak March terkenal oleh keramahan mereka, mereka tidak membedakaan antara si kaya dan si miskin, saat mereka masih menjadi keluarga yang berada, anak-anak March tidak segan bermain dengan bermacam kalangan status sosial ekonomi. Saat keluarga March terpuruk mereka tidak pernah menebar rasa benci, iri kepada orang yang lebih beruntung dari pada mereka.

Hasil analisis data tersebut, hal yang patut untuk dicontoh, sikap menerima dan bebas dari rasa iri dan dengki, tidak membedakan satu sama lain, karena bukan uang yang memberi kita kebahagiaan tetapi dengan banyak teman kita bisa bahagia.

\footnotetext{
"akulah pria dalam rumah ini sekarang karena Ayah sedang pergi, dan aku lah yang akan membelikan sepatu untuk Ibu, karena Ayah menyuruhku untuk memberi perhatian khusus kepadanya selama Ayah pergi"
} 
FON : Jurnal Pendidikan Bahasa dan Sastra Indonesia

Volume 14 Nomor 1 Tahun 2019

Pada kutipan data tersebut Jo mempunyai tanggungjawab selama ayah nya sedang berjuang dimedan perang. Jo mempunyai tanggungjawab untuk memberi perhatian penuh kepada ibunya.

Hasil analisis data tersebut, sikap Jo yang terlalu kelaki-lakian membuat ayahnya memberi tanggungjawab penuh selama ayahnya sedang berjuang di medan perang untuk menjaga ibu dan adikadiknya.

\section{KESIMPULAN}

Perempuan yang memiliki peran ganda akan merakan beberapa kendala dalam menjalankan semua perannya. Kendala yang pertama terdapat dari dalam diri perempuan itu sendiri yaitu keterbatasan waktu yang menyebabkan lelah fisik dan mental. pengasuhan anak akan terabaikan karena waktu yang dimiliki terbatas. Dalam novel Little women karya sastra asing yang banyak sekali pembelajaran yang dapat diambil karena novel yang mengusung cerita kehidupan sehari-hari menjadikan mudah. Dimana bisa mendapatkan banyak pembelajaran hidup seperti taat pada agama, berbagi kepada sesama tanpa melihat kaya atau miskin, serta pada pendidikan anak-anak keluarga March membuat "terdidik" namun tidak merasa "digurui".

DAFTAR PUSTAKA

Alcottt, Louisa. (1868). Little Women. Boston, Massachusetts: Robert Brothers.
Hayati, Y. Dunia Perempuan Dalam Karya Sastra PerempuanIndonesia. Citra Perempuan, 11, 85-93.

Karim, A. (2014). Feminisme Sebuah Model Penelitian Kualitatif. Sawwa, 10, 316-322.

Prabowo, D. E. (1 juni 2011). Peran Ganda Perempuan dan kesetaraan Gender. Muwazah.3.350-358.

Ratna, N. K. (2014). Gerakan Feminisme. Citra Perempuan, 2, 3-14.

Salaa, Jeiske. (2015). Peran Ganda Ibu Rumah Tangga dalam meningkatkan Ekomoni Keluarga. Jurnal Holistik. Vol.15, No.08

Anshori, DS, E Kosasih \& F. Sarimaya. (1997). Memperbincangkan Feminisme. Bandung: Pustaka Hidayah.

Mudyahardjo, Redja, (2009). Pengantar Pendidikan, Sebuah Studi Awal Tentang Dasar-dasar Pendidikan Pada Umumnya dan Pendidikan Di Indonesia. Jakarta, Raja Grafindo Persada.

Beilharz, Peter. (2002). Teori-teori sosial, Observasi kritis terhadap para filosof terkemuka. Yogyakarta: Pustaka Pelajar.

Siregar, M. (2007). Keterlibatan ibu bekerja dalam perkembangan pendidikan anak. [Jurnal]. Universitas Sumatera Utawa. Vol. 02, No.01.

Mardikanto, T. (1990) Wanita dan keluarga. Surakarta: PT Tri Tunggal Tata Fajar. 